\title{
A Study on the Application Value of English and American Literature in College English Classroom Teaching
}

\author{
Wang Chen \\ Shaanxi Technical College of Finance and Economics, Shaanxi, China, 712000
}

Keywords: College English; Classroom Teaching; British and American Literature; Application Value

\begin{abstract}
With the development of quality education, the new curriculum reform requires higher and higher requirements for college English classroom teaching. It requires that English and American literature be fully used in College English classroom teaching, so as to cultivate interlanguage competence and promote the improvement of students' own quality and cultural accomplishment. Generally speaking, the application of English and American literature in College English classroom teaching can expand the content of the textbook, change the traditional single teaching method, give full play to the leading role of teachers and students, stimulate uninteresting in learning, improve the effectiveness of College English classroom teaching, and achieve the goal of comprehensive English quality teaching.
\end{abstract}

Since the reform and opening up, the overall level of College English teaching has improved significantly, and the results are obvious to all. However, with the rapid development of College English teaching, there are still many problems. For example, in teaching, we attach importance to solving the problem of understatement of language knowledge and skills, neglecting the cultural knowledge related to language, especially the cultivation of students' humanistic qualities; in teaching practice, we often focus only on the explanations and tests of vocabulary and language points, and regard CET-4 and CET-6 as a lever to measure teaching level; only focus on the instrumentality of language teaching, and pay less attention to humanism.

According to the Basic Requirements of College English Course Teaching, College English teaching must change the educational concept, innovate the teaching content and curriculum system, improve teaching methods and teaching means, improve the testing and evaluation system, create a three-dimensional and diverse learning environment and atmosphere for students, improve the quality of College English teaching, and meet the needs of the country and society for personnel training. Therefore, from the perspective of cultural philosophy, the combination of instrumentality and humanism in teaching reform and research has certain significance for enriching the current college English teaching theory. 


\section{Investigation on the Integration of British and American Literature Knowledge into College English Teaching}

In order to understand the present situation, necessity and feasibility of the integration of English and Chinese literary knowledge into college English teaching, we conducted a questionnaire survey among undergraduates of Hen an College of Animal Husbandry Economics in order to understand the current situation of College Denuclearizing of English and American literature, their views on the integration of English and American literature into College English teaching, teachers' roles in teaching and so on, and to collect relevant data. According to the screening, analysis and discussion.

According to the survey of the views on the integration of English and American literature education into college English teaching.

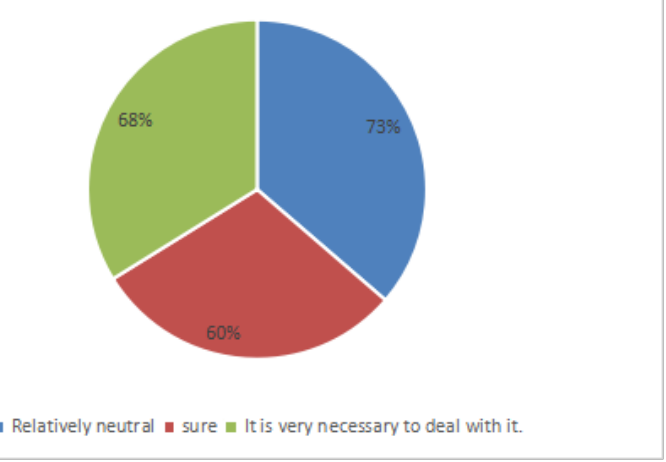

Figure 1 The views on the integration of English and American literature education into college English teaching

As shown in figure 1, the majority of students (73\%) have neutral attitudes towards English and American literature; $60 \%$ have positive attitudes towards English and American literature learning; and $68 \%$ believe that it is necessary to involve English and American literature knowledge in College English classroom teaching. The results show that most students are interested in English and American literary works, and are willing to incorporate certain knowledge of English and American literature into English language learning to improve the efficiency of second language acquisition and literary literacy, and promote the improvement of language ability and personal comprehensive quality. Therefore, it is feasible to infiltrate English and American literary knowledge into college English teaching.

According to the survey of the current situation of studentship and American literary works learning, the frequency of students' reading English and American literary works is generally not high, $76 \%$ of them only read occasionally, and most students can spare 1-2 hours a week or half an hour a day to study English and American literature. In addition, the survey of learning efficiency shows that most of the students (60\%) are not confident in English and American literature learning and have weak problem-solving ability. Therefore, it is necessary to explore and study the teaching of English and American literature in the process of College English teaching in order to find a suitable teaching mode for students to integrate into each other.

According to the survey of bleacher in teaching, 65\% of them believe that teachers should provide students with the help they need to learn English and American literature; $54 \%$ of them should show their personal charm and knowledge in class; and $80 \%$ of them should encourage students. The proportion that teachers should play their roles in the classroom is relatively high, and some students also want feedback from teachers (12\%) and regular tests (8\%). From this survey, it can be seen that students hope to get the help of teachers in English and American literature learning in College English class. They hope that teachers can conduct regular tests, give positive 
feedback and show their own personality and knowledge charm.

The survey results show that it is feasible to teach English and American literature in College English courses. Most of the students are interested in English and American literary works and are willing to incorporate certain knowledge of English and American literature into English language learning so as to improve language acquisition efficiency and literary literacy and personal comprehensive cultural literacy.

\section{Problems in College English Classroom Teaching}

\subsection{Backward Teaching Mode}

Generally speaking, College English is a comprehensive subject, which includes the cultivation of glistening, speaking, reading and writing abilities. In the process of College English teaching, a teacher often needs to cultivate studentship abilities. Although this can effectively save resources, it will increase the pressure and task of teaching to a certain extent, and it is difficult to effectively promote the improvement of students' English level. In addition, some teachers still use the traditional teaching mode in English teaching activities, unable to effectively use modern educational technology, difficult to integrate English teaching and information technology, resulting in poor teaching effect and quality, and difficult to promote the improvement of interlanguage use ability.

\subsection{Insufficient enforcement of teaching requirements}

Teachers in College English teaching activities do not strictly comply with the relevant provisions of College English Teaching Requirements. They still adopt the teaching mode of indoctrination and cramming. They can not organically combine English and American literature with college English teaching. As a result, enthusiastically for learning is reduced, their subjective initiative cannot be fully mobilized, and their comprehensive ability to use English and literary literacy can not be effectively improved. In addition, in order to meet the requirements of the new curriculum reform, some colleges and universities install advanced language equipment and effectively set up relevant language multimedia classrooms. However, in the actual college English teaching activities, these language devices are not properly and fully used, resulting in a large waste of resources, which is not conducive to the improvement of the effectiveness of College English classroom teaching.

\section{The Applied Value of English and American Literature in College English Classroom Teaching}

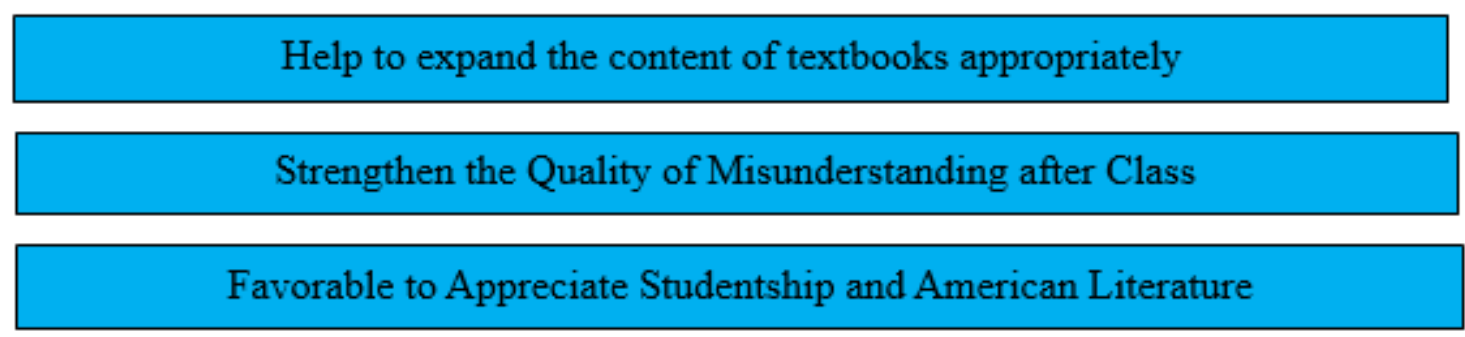

Figure 2.The Applied Value of English and American Literature in College English Classroom Teaching 


\subsection{Help to expand the content of textbooks appropriately}

College English textbooks cover a wide range of contents, such as culture, history and society, and include many literary works. Therefore, in College English classroom teaching activities, teachers should grasp the contents of textbooks scientifically and apply English and American literature rationally, so that students can deeply grasp literary knowledge and cultivate their literary aesthetic ability. For example, when explaining the contents of the fourth volume of New Horizon College English Reading and Writing Course, teachers can expand the characteristics of Oscar Tilde's works according to his experience, so that students can understand his personality and unique aesthetics. Then in the classroom teaching, we analyze the relevant fragments of its classics to attract sentimentalization and improve the effectiveness of teaching.

\subsection{STRENGTHEN the Quality of Misunderstanding after Class}

Classroom learning is an important part of studentship learning. Teachers should not only cultivate students' literary awareness in classroom teaching, but also incorporate the cultivation of literary awareness into transcendentalists learning, so as to improve the quality of students' after-class reading. Generally speaking, reading is an important way to cultivate studentship ability. If teachers do not pay attention to students' reading, it will be difficult to improve studentship ability. Therefore, when teachers apply English and American literature to college English classroom teaching, they must encourage students to actively carry out after-class reading, so as to effectively overcome the obstacles of English language and think deeply about the connotation of English and American literary works.

Of course, when applying English and American literary works, teachers should combine studentship ability and recommend literary works that are easy to understand to students so as to arouse students' interest in reading. Then, combining with the reading effect, the reading content of the next stage is reasonably set up, and the students can record the reading results, consolidate the understatement, and promote the improvement of students' writing thinking ability.

\subsection{Favorable to Appreciate Studentship and American Literature}

When applying English and American literature in College English teaching, teachers should guide students to understand the development of English and American literature, so that students can accurately orientate the era of works in the process of reading. At the same time, teachers can use special class hours to explain the general situation of British and American literature, such as the characteristics of literature development in the period of realism, Romanticism and Renaissance, and analyze the writing style of outstanding talents in these periods. In this way, students can think and analyze the content of the text through clear thinking in the process of reading works. In addition, teachers should properly explain the appreciation methods of literary works in the teaching process, such as stylistic analysis, character analysis, text reading, etc., to strengthen studentship ability.

\section{Conclusion}

As an international language, English is an important bridge for people to understand the world and go to the world. Therefore, in the process of College English classroom teaching, teachers must scientifically apply Anglo-American literature, properly expand the content of textbooks, strengthen the quality of transcendentalists reading, and appropriately point out the appreciation methods of Anglo-American literature. Only in this way can we stimulate uninteresting in English learning, 
cultivate students' language use ability, improve transcendentalist aesthetic ability and cultural quality, promote the effectiveness of College English classroom teaching, and realize the sustainable development of higher education.

\section{References}

[1] Tan Ieyasu, Li Jungian. Strengthening English and American Literature Teaching in College English Teaching Reflections [J]. Education and Teaching Forum, 2011

[2] Duane, Li Jun. The Current Situation of English and American Literature Teaching in College English Classroom Challenges [J]. Reading and Writing (Educational and Teaching Journal), 2011

[3] H Xiaoping. The Positive Role of British and American Literature Appreciation in College English Teaching [J].Weenie (Mid-term Journal), 2011

[4] Han Whaling. On the Combination of College English and English and American Literature Teaching [J]. Higher Finance and Economics Teaching Education Research, 2013

[5] Ch eng Inyanga, Freshen, Fao Youngish. Exploration and Practice of Humanistic Quality Training in College English Teaching in Science and Engineering Colleges [J]. Shannon Foreign, 2009 